\title{
The African Renaissance and children's literature: is South African librarianship abdicating its role?
}

\author{
Genevieve Hart \\ Department of Library \& Information Science, University of the Western CapeCape Town, South Africa \\ Ghart@uwc.ac.za
}

Received: 22 March 2002

Revised: 28 April 2002

\begin{abstract}
Traditionally, the library profession has taken a leadership role in the domain of children's literature - as part of its social mission. In apartheid South Africa, librarians were responsible for research units, for prestigious awards and for the professional competencies of children's librarians. In championing children's literature, librarians might contribute to the African Renaissance - the nation-building ideology being promoted in post-apartheid South Africa. The project that prompted this paper investigated the position of children's literature in the education of librarians within 15 universities and technikons. It found children's literature education to be in a precarious position with most of the historically advantaged institutions having dropped it. Those that retain children's literature modules have inadequate resources. The apparent low priority given to children's literature within the profession might be due to an unfortunate combination of pressures - within library employing organisations, the professional association and tertiary education.
\end{abstract}

\section{Introduction}

This paper is the result of a research project in 2001 that investigated the position of children's literature specifically South African children's literature - in the professional pre-service education of librarians in South Africa. However the article is more than a mere summary of the findings of this study. The author's central purpose is to explore the context of the project and to reflect on its implications for the library profession in South Africa. As will be discussed below, traditionally librarianship has taken on a leadership role in the field of children's literature. This leadership role has rested on solid professional education in children's literature. This education is, firstly, aimed at providing the professional competencies needed by children's librarians. But it also surely aims at enabling the profession to continue to take the lead in the development of children's literature. From early in the 20th century librarians have taken responsibility for the nurturing of children's publishing. This role is seen to be part of their social mission.

The research project followed the author's earlier study of 67 children's librarians in Cape Town, which revealed that less than half of them had a professional qualification, and that only half of these had had formal education in children's literature in their professional pre-service education (Hart, 1999b). These findings were surprising, as a preliminary survey of the international literature had led to the assumption that one of the basic competencies for children's librarians required by employing authorities was knowledge of children's literature. Another assumption had been that South African departments of library and information science (the so-called "library schools") were providing that education. There was consensus among the children's library staff in the study that they needed more education in children's literature to perform their jobs effectively. Only one of the six metropolitan sub-structures at that time was providing formal in-service training in children's literature for newly appointed children's library staff. This study pointed to the need for a follow-up investigation of the position of children's literature in librarian education in South Africa.

The rationale for the investigation came out of concern that, if indeed it is abandoning its traditional leadership role in the domain of children's literature, South African librarianship might be abdicating a significant national role. Internationally the credibility and prestige of professional librarian bodies surely emanate from their contribution to the building of and communicating of the cultural identity of their nations. The African Renaissance is an ideology being constructed by intellectuals and politicians to offer a new sense of identity and pride to post-apartheid South Africa (Serote, 2000: 181). The argument in this article is that children's literature is closely intertwined with a nation's culture and identity. It thus offers an opportunity for the library profession to make a significant contribution to the nation-building implicit in the African Renaissance movement. 


\section{Children's literature and librarianship}

As shown in official statements on their web sites, professional associations like the International Association of School Librarians, the American Library Association and the Library Association in the UK still list expertise in children's literature as an essential competency for children's and school librarians. The relationship of children's and youth librarians to children's literature goes beyond workplace competencies. Thus the 1992 British Arts Council and Library Association report on public libraries described children's librarians as the "guardians of children's literature" (Reading the future, 1992: 42).

However, a thread of concern is discernible in the international literature throughout the 1990s over the weakening position of children's librarians in professional ranks (for example Elkin \& Lonsdale, 1996: 57, 239). Several surveys of public and school libraries were undertaken in the 1990s in the United Kingdom (for example Department of National Heritage, 1995; Streatfield \& Davies, 1995). Scattered through their reports are comments that reveal concern over the reduction in the number of children's librarianship and children's literature courses offered in librarians' professional education and training. There was speculation that the shrinking of the public library market for new graduates in countries like the United Kingdom had impacted on library school curricula. New information and communications technologies had put pressure on library schools to provide courses that equipped their students with advanced ICT skills. In a climate of staff cutbacks, universities had examined their programmes and had made hard choices. The result was that children's literature courses had lost ground in professional education internationally.

South African librarians need to listen to these voices of concern, especially as children's literature, both internationally and within South Africa, has largely been the domain of librarianship. If indeed the library profession is losing its position as a major role player in the domain of children's literature, then the profession has to be aware of this trend and its implications.

\section{Children's literature - the domain of librarians?}

The buying power of libraries - school and public - has always been a factor in the powerful position of the library profession in children's publishing. In marketing their books, children's publishers target schools and libraries since children themselves do not buy books in large quantities. The influence of the educational book-buying market in South Africa has been much commented on (Jenkins, 1993: 5; Machet, 1993: 167). The strong ties between publishing and education structures in apartheid South Africa were a factor in building up a strong national children's publishing industry, at least in the English and Afrikaans languages.

National library associations established the major prestigious prizes for children's literature (such as the Newbery and Carnegie Medals) in the first half of the 20th century. Their purpose was to improve both the quantity and quality of children's books in their nations (Tötemeyer, 1993: 100). The South African Library Association (renamed the South African Institute for Librarianship and Information Science in 1980) followed their example when it set up a series of prizes for South African children's books - in English \& Afrikaans - in the 1950s, 1960s and 1970s (Kruger, 1991). These prizes did not survive the demise of SAILIS. However some were picked up by other organisations such as the English Academy of Southern Africa and the South African Children's Book Forum.

Professional library associations have always provided room in their journals and at their conferences for children's literature - as evidenced in the past in the conference proceedings and journals of South African library associations.

Library schools both internationally and here in South Africa have traditionally played a strong role in the children's literature arenas of their countries. This role goes beyond the provision of training courses to their students. A new role, for example, is the hosting of Internet discussion groups which allow easy expansion beyond national boundaries - such as the Childlit listserv hosted by Rutgers University's School of Communication, Information and Library Studies.

The University of the Western Cape's Department of Library \& Information Science hosted two conferences in 1987 and 1992 - which led to the formation of the South African Children's Book Forum (SACBF) (Cilliers, 1988; Cilliers, 1993). Tötemeyer (1993) sees the first of these as a turning point in a national recognition of the needs of South African black youth. The University of South Africa's Department of Information Science held a large international gathering in 1995 which again focused attention on the need for a multicultural South African children's literature (Machet, Olën \& Van der Walt, 1996). 
Library schools within universities also established South Africa's research units for children's literature ISKEMUS at Stellenbosch University, the Institute for Research in Children's Literature at Potchefsroom University for Christian Higher Education and the Children's Literature Research Unit at the University of South Africa. These units acted as clearing houses and resource centres for librarians and for educators. It is apparent both in South Africa and overseas, that, apart from the education in children's literature offered within library school programmes, librarians are commonly responsible for maintaining children's literature collections and for teaching modules on children's literature in teacher education institutions.

A final point in this summary of the prominent position that the library profession has occupied in the field of children's literature is its involvement in other forums. A glance at the committees and membership lists of children's literature associations such as the International Board on Books for Young People (IBBY) and the South African Children's Book Forum shows that librarians play an important part in their activities.

\section{Children's literature and the social mission of librarianship}

The discussion in the preceding section has shown that the involvement of librarians in the domain of children's literature goes beyond the concern that they have the competencies needed for their work - although this is of course essential. It is also more than the belief that reading children become reading adults. At gatherings of children's librarians the refrain is often heard that "in serving children we are serving future adult library members". Although this belief might well be true, the involvement of the profession in children's literature goes beyond growing library membership figures.

As shown above, since the early 20th century the various national professional associations have taken the lead in the development of children's literature in their countries. This leadership stance is rooted in the social and cultural mission of the library profession. In putting the case for national children's literatures in post-colonial societies, a meeting of activists in Delhi in 1993 described books as "instruments of educational development, social growth, cultural preservation and meaningful communication" (Formulating the National Book Policy, 1993: 19). This phrasing surely resonates with the traditional mission statements of the library and information profession, which commonly stress its educational, cultural and communication functions in society.

In contributing to children's literature, librarianship is contributing to the education and culture of a society in a way that perhaps no other profession can. Hunt (1994: 17) distinguishes two categories of people within the field of children's literature - the literary critics on one side and teachers and parents on the other. He warns that the result is that discussion is often polarised between so-called "book people" and "child people". Librarians might claim to be both "book people" and "child people". They thus might claim a wider view than literary specialists, publishers or educators.

\section{Children's literature and education}

Aidan Chambers, a leading children's author and commentator in the UK, describes the role of adults in getting children to read as an enabling one (1993: 5). The potential role of librarians in developing children's literature collections that are meaningful to young readers is suggested in evidence that to learn to read with enjoyment children need two things:

interesting materials that make sense to the learner and an understanding adult as a guide (Smith, 1978 in

Wray, Bloom \& Hall, 1989: 82)

More research is needed in South Africa to find out whether children's and school librarians are indeed giving this kind of guidance. The recent pilot study by UNISA's Children's Literature Research Unit within schools in Pretoria throws some doubt on the influence of librarians on the reading behaviours of South African children. Only a small minority of their respondents mentioned librarians as significant support people in their choice of books (Machet, Olën \& Chamberlain, 2001: 24). It is likely that the shortage of school and children's librarians, who are able to provide this kind of active reading advisory service, is preventing the profession from assuming this important role.

Research has shown that children who read well perform better academically across the curriculum (Krashen, 1993). The production of good juvenile literature in local languages might well foster the reading habit (Formulating the National Book Policy, 1993: 20; Ogunrombi \& Adio, 1995: 55). Enjoyment in reading has been shown to depend on access to appealing books - that is, books in one's own language, books that look good, books that tell engaging stories. The more a child chooses to read the easier she will find it - and the easier she finds it the more she will then choose to read. As Flanagan (1995: 3) says, "learning to read is done by reading, and more and more and more reading, however young or old you may be". 
The phasing in of South Africa's transformed curriculum (Curriculum 2005) has revealed new evidence of the poor reading abilities of South African learners. The report of the President's Education Initiative Research Project, which set out at the end of the 1990s to assess how Curriculum 2005 was faring, concludes that the historically disadvantaged school sector is struggling to cope with the new emphasis on independent discovery learning (Taylor \& Vinjevold, 1999). Vinjevold and Taylor, the editors of the report, which summarises 32 separate research studies in 300 schools throughout South Africa, find that "books are very little in evidence and reading is rare" (1999: 231). Teachers seem to rely on ad hoc activities and disconnected worksheets, to the detriment, the report warns, of higher order thinking skills. The danger is that "without books to read and write in, schooling as cognitive development cannot happen" (Vinjevold \& Taylor, 1999: 233).

This report perhaps supports the claim by the READ Educational Trust (1998: 3) that South Africa's high matric failure rates are caused by learners' inability to understand their textbooks. The rote learning that schools relied on in the past perhaps concealed the truth - that South African children leave school with very low levels of literacy. Recent support for this view might be found in the study by UNISA's Children's Literature Research Unit of the reading habits of children in English medium schools in Pretoria that was mentioned above. The study found evidence that South African children do not read very much (Machet, Olën \& Chamberlain, 2001: 133). It suggests that a shortage of interesting books in the mother tongues of South African children might be contributing to the lack of reading (Machet, Olën \& Chamberlain, 2001: 139).

The shortage of books in the vernacular has an impact on children of all ages. South Africa's Centre for the Book has identified a gap in children's publishing for early childhood in this country (Centre for the Book, 2002). Its First Words in Print initiative aims at producing a series of South African books for toddlers in a range of African languages. Its motivation is the research that shows that children who have no access to books before they go to school are severely disadvantaged and have trouble catching up with other children. It also alludes to the evidence that access to reading material in one's home language is a major factor in the development of early literacy (Centre for the Book, 2002). Machet and Olën (1997) might provide some of this evidence in their study of the literacy environment of children in a disadvantaged primary school in a South African township. They show the literacy environment to be impoverished and to provide an inadequate preparation for school learning.

Young children's need for books in their home language is a larger issue than school readiness. Books can help nurture a child's emerging sense of self. In post-apartheid South Africa, children need books that reflect themselves and affirm their own experiences. In 2001 the Centre for the Book recognised these perhaps more ideological issues and convened a symposium, Creating One Voice, that explored the role of children's literature in the so-called African Renaissance. The underlying assumption was that children's literature has a role to play in building a South African cultural identity.

\section{Children's literature and the African Renaissance}

The construct of an African Renaissance is being promoted by the South African government as an ideology to restore pride and a sense of common national identity in post-colonial and post-apartheid South Africa. In his collection of essays on African intellectualism, Mongane Wally Serote (2000), a leading proponent of the African Renaissance movement, traces the various political, economic and cultural strands within the ideology. He describes it as a "process" that "must shift paradigms and reconstruct points of reference to let emerge an African consciousness which seeks to entrench democracy, non sexism, non-racialism as pillars for a socio-economic system which guarantees quality of life for all" (Serote, 2000: 187). As Serote points out, the African Renaissance ideology is not just for Africans; indeed it offers a vision of a new world order in which the world becomes "a liveable place for all" (p. 210). However, its primary intention is perhaps to address the need for a renewal in Africans' views of themselves. Serote (2000: 57) argues that centuries of European colonialism have bred what he calls a "timidity" among Africans - a lack of confidence in their own culture and traditions. Literature clearly has a role to play in the building of the African consciousness that Serote talks of. Any discussion of the role of literature in nation building has to look at language - a key aspect of culture and identity. Literature and language are intertwined in that they both carry a nation's sense of self and culture (Serote, 2000: 53). Since the first democratic elections in 1994, South Africa has embraced, in its constitution and its official policy documents, the ethos of multilingualism and multiculturalism - in which previously marginalised cultures and languages are valued and supported. The Pan 
South African Language Board is an instrument expressly designed to promote this ethos. But, as Serote (2000: 57) points out, literature in African languages has been marginalised - after centuries of European colonialism.

Experience in other post-colonial countries like Canada suggests that a children's literature can be a vehicle for the building of a sense of heritage and identity (for example Saltman, 1987; Paul, 1989; Carpenter, 1996). As Carpenter points out, children's literature has always been used by adult society to "colonise, manipulate and control" (1996: 70). To support her claim, she shows how Canadian children's publishing has been enlisted in the ideological goals of multiculturalism since the Canadian constitution enshrined it in 1971. She (1996: 53) concludes that "literature functions as a cultural product that both reflects and shapes the culture of those who live it". Speaking of how Africa and Africans are portrayed in so-called neo-colonialist juvenile fiction, Maddy and MacCann (1996: 10) echo Carpenter in quoting the sociologist Joan Rockwell who describes fiction as a "social product", which also "produces society because it has a normative effect on its members, perhaps especially in childhood".

Jenkins (1993: 52) identifies the 1950s as the time when English language children's literature in this country began to explore what it meant to be South African, as opposed to English. Reading the children's books and school readers of the 1950s today gives the impression that to be a South African meant to be an intrepid hunter - tracking down poachers and rogue animals. It was part of the myth-making needed by English speaking South Africans - a kind of laying claim to a cultural identity. Jenkins (1993: 57) calls this trend the Bushveld Syndrome. The fact that the vast majority of these books' readers were urban, with no experience of the bush, was beside the point. Afrikaner cultural organisations similarly realised the need for culture-building literature - literature that affirmed their values and norms (Tötemeyer, 1993: 100). Tötemeyer's PhD thesis (1984) shows how much of Afrikaans children's literature throughout the 1960s and 1970s both reflected and promoted the prevailing ideology of white superiority and black subservience.

We might not like the messages of the past, but we cannot deny the power of children's literature as an ideological vehicle. There is concern in other post-colonial countries that children who are brought up on a diet of foreign books lose touch with their own cultures and values (Formulating the National Book Policy, 1993). Black children need to see themselves and their culture in their books if they are to build a sense of their own worth and identity. There is widespread belief that a strong national literature is crucial to the "nation-building" that a fragmented society like South Africa so clearly needs.

The suggestion here is that, in championing South African children's literature, South African librarianship might become a role player in the African Renaissance.

\section{The current position of South African children's literature}

However, even if there were today generous injections of funds into disadvantaged school libraries, it is clear that it would be hard to fill their shelves with books in the languages needed (Totemeyer, 1993: 101). The shortage of books in South Africa's indigenous languages has already been alluded to. As suggested at last year's symposium at the Centre for the Book Creating One Voice, one strategy to kick-start indigenous publishing might be large scale translation projects. These might translate the world's best children's books and the best of South African English writing into African languages. Exposure to a large range of interesting books might eventually create the kind of literary awareness that will nurture a new generation of South African authors. However, such projects will perhaps depend on what might be called "political will" - from within the ranks of government as well as the professional associations of librarians, educators and publishers.

There is evidence that most of our black children's authors write and publish in English. According to Diamond (1996: 117), only five original African language books were published for children in 1994. It was also estimated at about the same time that about $90 \%$ of children's books in African languages were translations for the school reader market (Lenake, 1996: 108). The situation has not improved much since the early 1990s, although attractive and original series of school readers are now more apparent. Despite the official embracing of multilingualism, the position of African languages might well have deteriorated in the so-called new South Africa. The number of students studying African languages at South African universities has apparently halved every year since 1995 (Students shun South African languages, Sunday Times, 2001). Parents are increasingly enrolling their children in English medium schools as they turn away from mother tongue instruction in Afrikaans or Xhosa (Johns, 2002). According to many educators, the result is that children speak and understand both English and their mother tongue badly. This hampers their acquisition of cognitive higher-order skills - negatively impacting on their learning across the curriculum (Alexander, 2002; Johns, 2002). In arguing for mother tongue education, Neville Alexander, director 
of the Project for the Study of Alternative Education in South Africa at the University of Cape Town, constantly warns that South Africans still suffer from a colonial mentality in believing deep down that their own languages cannot perform as English does (for example Alexander, 2002).

The above discussion has pointed to the precarious position of children's publishing in South Africa. This position is due partly to the loss of "guaranteed" sales to school and library systems since 1995. In the last few years, a major children's picture book publisher has gone bankrupt. Another, which specialises in translating the world's prize-winning picture books into South Africa's indigenous languages, has held back its publishing of a number of manuscripts for over a year, as it cannot be sure of the minimum number of sales to cover costs. The restructuring of public library systems has led to reduced spending on children's books. And shifts to site-based management of schools have brought an end to the old centralised buying policies in our school systems. Schools within disadvantaged communities, which are faced with many competing demands, do not often prioritise the development of the school library. There is evidence that many school libraries in South Africa, especially those within the ex-House of Representative and ex- House of Delegates schools, have been closed after the retrenchment or redeployment of their staff (Hart, 2000b). It is common knowledge that the salaries of many of South Africa's remaining school librarians, as well as their book budgets, come from so-called governing body funds. This of course implies that schools that cannot gather funds from their communities struggle to maintain effective library collections.

The author's earlier studies within schools and public libraries led to questions as to the position of children's literature in schools and public libraries. The classrooms visited in the course of two projects conducted in a circuit of schools in Cape Town in 1998 were mostly bare of books (Hart, 1999a; Hart, 2000b). Many teachers seemed to rely on outdated tatty readers and seemed ignorant of the need for attractive reading materials. Yet they all expressed concern over the reading abilities of their learners. The study within public libraries the following year questioned the capacity of public libraries to step into the gap. As mentioned above, the author's study of 67 children's libraries in Cape Town in 1999 concluded that the position of professionally qualified children's librarians was being eroded (Hart, 1999b). Just less than 50\% of the 67 had a professional qualification in librarianship, and only a quarter had any formal training in children's literature.

\section{Children's literature in librarian education in South Africa: 2001 Research study}

The above discussion has provided the rationale for the investigation in 2001 into the position of children's literature in the education and training of South African librarians. It seems obvious that the traditional prominence of librarianship in the domain of children's literature must depend on a solid base of professional expertise and knowledge. It thus depends on children's literature education and research in professional education programmes.

The study was based on two premises: that a national children's literature plays a part in nation building; and that librarianship has a special responsibility for the nurturing of a society's children's literature.

These beliefs are shared by researchers in other post-colonial countries. In 1989 Paul, for example, counted 161 courses in children's literature in tertiary institutions in Canada. Despite the fact that Canada had what she called a "flourishing community of high quality children's writers" she still described the place of Canadian books in these courses as a "sensitive issue" and indeed found that only $20 \%$ of books taught in children's literature courses were Canadian (Paul, 1989: 43). She attributed this low figure to the residue of Canada's colonial past and its geographic position next to the giant market of the USA.

The author's project set out to answer the following questions:

- What is the position of children's literature in South African library and information science education?

- What specifically is the position of South African literature in the curriculum?

- Has the position changed in the past few years?

- What are the challenges facing teachers of children's literature?

To answer these questions, 15 of the 16 departments of Library and/or Information Science within universities and technikons throughout South Africa were contacted. There are two gaps: RSA Technikon's Department of Library and Information Studies, and an interview with the children's literature lecturer at the University of Zululand, who was on leave. The first step was usually to speak to the Head of the Department to gain a general picture of what courses in children's literature were offered and to be put in touch with the academics responsible for children's 
literature. These academics were then interviewed - using a fairly structured questionnaire. Some of the interviews were face to face; others were by telephone. The questionnaire included several open-ended questions designed to gather more qualitative data.

The following section makes no attempt to give a complete and systematic report on the data gathered question by question. It rather highlights the main findings in order to explore the implications of the survey for children's literature and for the library profession in this country.

\section{Summary of findings}

Of the 15 departments, three are no longer offering librarian education (University of Stellenbosch, Potchefstroom University for Christian Higher Education, and Rand Afrikaans University) and one had just heard that it was to be closed in the next two years (Cape Technikon). Others, the Universities of Cape Town and Pretoria, had dropped their courses in children's literature in the 1990s. It was reported that this decision was taken when their curricula were being reviewed and they were facing increasing pressures to provide new ICT courses. The University of the North offers a one year certificate course in library science for school leavers, run by the University Librarian, which does include some introduction to children's literature.

Overall eight library schools were found to retain children's literature courses in their programmes. About 18 children's literature courses were identified on the programmes of these eight institutions - with only five being part of initial basic professional training. The length of these basic modules or children's literature sections are similar in all institutions - with each module or section having about 23 hours of formal contact teaching. All the courses are restricted to library science students, although two respondents in universities are attempting to open up their courses to other programmes. All courses are given in English.

Five of the 18 courses are in reality dormant, as no students have signed up for them for a few years. These are either courses within Diplomas in School Librarianship, which have experienced hard times in the last few years with the failure of national school library policy, or elective courses in post-graduate programmes. On being asked why students are not choosing these courses, most respondents reported that students perceive ICT courses to be more useful in their careers. Several respondents expressed their concern at this - pointing out that many of their graduates are destined to work in public libraries, which surely need expertise in children's literature.

Of the eight children's literature specialists, only one was male. Four were English speaking, one Xhosa, one Setswana, one Sotho and one Afrikaans. Only two had senior status - although their average age was 48 years. Five had a Masters Degree, one had a PHD and two were completing their PHD theses. The dominance of women and their relatively junior status follow patterns elsewhere in the world (Hunt, 1994: 7).

It is significant that the shifts away from both librarian and children's literature education have taken place in the so-called historically advantaged institutions (HAIs) - two of which housed the children's literature research collections (ISKEMUS at Stellenbosch and the Institute for Research in Children's Literature at Potchefstroom). The future of these two research units is uncertain. The remaining children's literature courses are, with one exception (Port Elizabeth Technikon), within historically disadvantaged institutions (HDIs). The significance here is that these institutions have been under-resourced over the years. The study revealed indeed that only one lecturer has a teaching collection of children's books in her department and only two receive some limited funds to buy children's books. Lecturers rely on their own books and local public libraries. However, several commented that their local libraries are poorly stocked and that their students struggle to get to the libraries.

On close examination, it became clear that even courses with identical names might have very different content and teaching approaches. For example, children's literature is included in the technikon courses usually labelled Readership or Literature Studies. Some of these expect their students to read and review children's books; others just talk about children's literature - covering selection criteria, a survey of the genres, and so on. Only the university courses called Children's Literature provide students with a core reading list of children's books. One respondent gave a clue as to how courses come to differ even within one department. She reported that when she went away on study leave she was replaced by someone who had no interest in or knowledge of children's literature. She arrived back to find the content and teaching approach in her courses changed and it was difficult to regain the lost ground. Similar comments from other respondents indicate that much depends on the enthusiasm of individuals.

The study finds little evidence of awareness of what might be called the African Renaissance issues discussed above. On average only $20 \%$ of the courses is devoted to South African literature. Three of the respondents include no South African materials at all - one of these three claiming that "our students need the basics". On further 
questioning, this respondent explained that by "the basics" she was referring to the English classics. She cites Grimms' fairytales as an example. Only one respondent explicitly encourages students to read African language materials for projects and essays.

Almost all attribute the weak position of South African books in their courses to the fact that they cannot find South African materials. However the depth of respondents' knowledge about contemporary children's literature might be questionable. A later question revealed that six of the eight respondents could not name a children's book that they had read in the past three months. Only three felt they were "adequately informed" on developments in the world of children's literature.

On being asked about their "challenges", the respondents reveal that they feel increasingly marginalised. Five comment that they feel they have to defend their courses - among both students and their colleagues who just do not understand the need for children's literature education. Morale amongst the respondents appeared to be low perhaps because of the sense of insecurity that prevails in higher education in this country.

The hazard all eight respondents mention is the challenge of teaching literature to a body of students who have done very little reading. All comment on the lack of reading culture among their students. One respondent in the Eastern Cape claims that South African youth have leaped from "an oral culture to a TV culture". The second most frequently mentioned challenge is the shortage of books in South Africa's indigenous languages. As mentioned just above, most give this as the reason why South African literature plays such a small part in their courses. Another common problem most academics bring up is a lack of resources. It seems clear that they need far better access to good collections of children's books if they are to give high quality courses.

\section{Study's conclusions}

The above summary of the study's findings has suggested the answers to the research questions posed by the study. It is clear that children's literature has lost ground in professional training and that it is indeed in a precarious position in South Africa's library education programmes. It lacks resources and also status. Comments from several of the respondents that they feel ill-informed might well indicate a lack of authority in their subject. The study uncovered contradictions between the declared commitment of respondents to the teaching of children's literature and the fact that they themselves seem to read very little. South African children's literature forms a very small part of the curriculum. All respondents agree that they would like more time allocated to children's literature, especially since most of their students have not been exposed to children's books in their homes and schools. But all were pessimistic that the present demands of the curriculum would allow this.

The overall conclusion thus is that South African librarians coming into the profession are, at present, being inadequately prepared to take the lead in the field of children's literature. It seems, moreover, that South African library schools are in danger of losing their traditional leadership position.

The project findings clearly imply a need for more collaboration among South Africa's library schools. Resources, meaning both expertise and collections of materials, need to be shared. Interventions - from education authorities, from the large library systems and from the Library \& Information Association of South Africa (LIASA) - are called for.

\section{South African librarians' abdication from children's literature?}

Whether South African librarianship - as a profession - retains the will to take a leadership role in the arena of children's literature of course cannot be taken for granted. The study described in this article perhaps serves to confirm the devaluing of children's literature in professional ranks. It can no longer be assumed that even public and school librarians have received an education in children's literature.

The survey of South Africa's library schools adds to the other signs that in recent years the library profession has withdrawn from its position in children's literature. These signs have been alluded to above and include:

- the loss to the profession of the children's literature research collections at the University of Stellenbosch and Potchefstroom's University for Christian Higher Education

- the demise of South African librarians' awards for children's books

- some evidence that the professional status of children's librarians is weakening (Hart, 1999b)

- some evidence that employers no longer insist that children's librarians have formal training in children literature (Hart, 1999b). 
The word "abdication" implies a conscious stepping down from a position. It also implies the handing over to a replacement. It is not clear who would take over librarianship's guardianship role in children's literature in this country. A second phase of the research project to investigate the position of children's literature in teacher education is at present being completed. However the readiness of the teaching profession to step in is doubtful. The same doubt holds with regard to the academic literary world.

Despite the rather gloomy picture painted above, it might be premature to talk of "abdication". The apparent professional withdrawal from the children's literature arena might not be the result of conscious decision-making. It could be that an unfortunate combination of factors - in tertiary education, public \& school library ranks and professional organisations - has conspired against children's literature within the library profession in South Africa.

Perhaps the problem is that South Africa's national library association, the Library \& Information Association of South Africa (LIASA), has not yet been able to step into the professional custodial role expected of other national associations. The apparent vacuum in leadership with regard to children's literature might well be due to timing rather than neglect. The end of apartheid brought a new credible professional association, LIASA, which clearly has needed time to establish itself. But during these early years of LIASA there have been shifts in libraries and in tertiary education institutions that have impacted negatively on the profession.

Government economic policies, for example, have led to harsh staffing cutbacks in the public sector where most librarians are employed. Confronting the pressures to restructure, employers might well have not prioritised the need for children's literature expertise. Much restructuring has taken place in the absence of an established professional association that might have acted as a watchdog - identifying and insisting on professional competencies, for example. LIASA is still taking the first steps towards the establishment of the Standards Generating Body that will enable it to adopt this role.

The shifting situation in tertiary education is clearly a significant factor. Decisions that might well impact on the profession and on library services throughout the country have been taken within institutions. Library schools have closed. Others have shifted direction, dropping so-called library courses but retaining so-called information science courses. These changes have taken place on an ad hoc basis without, as far as is known, any consultation with LIASA.

\section{Conclusion: the African Renaissance as opportunity}

The intention in this article has been to alert South African librarians to the weakening of their position with regard to children's literature. The apparent loss of ground has implications for services to young people in school and public libraries - and so for the profession's contribution to South African education.

But there are more philosophical and more strategic implications that require spelling out. If indeed South African librarians give up their responsibilities with regard to children's literature, it will mean that the profession will miss the opportunity to play a part in the national project of the African Renaissance. The profession is, arguably, in need of a vision that might enhance its position in the new South Africa. The cause of an indigenous South African children's literature within the framework of the African Renaissance could provide it with both a vision and an opportunity for practical action.

\section{References}

Alexander, N. 2002. Speaking up for languages. Cape Argus, February 15: 10.

Carpenter, C. 1996. Enlisting children's literature in the goal of multiculturalism. Mosaic, 29(3): 53-73.

Centre for the Book. 2002. First words in print. [online]. Available: www.nlsa.ac.za/cb/projects/fwip..

Chambers, A. 1993. Tell me: children, reading and talk. Stroud: The Thimble Press.

Department of National Heritage. 1995. Investing in children: the future of library services for children and young people. London: HMSO.

Cilliers, I. 1988. Towards understanding: children's literature for Southern Africa. Cape Town: Maskew Miller Longman.

Cilliers, I. 1993. Towards more understanding: the making and sharing of children's literature in Southern Africa. Cape Town: Juta.

Diamond, D. 1996. Children's books in African languages: translations, adaptations or new materials. In Machet, M., OlNn, S, Van der Walt, T. Eds. Other worlds other lives: children's literature experiences. Volume 3. Pretoria: UNISA Press: 116121.

Elkin, J. \& Lonsdale, R. 1996. Focus on the child: libraries, literacy and learning. London: Library Association 
Flanagan, W. 1995. Reading and writing in junior classes. Cape Town: Maskew Miller Longman.

Formulating the National Book Policy: need and guidelines. Report of the UNESCO/APPREB Sub-Regional Consultation on National Book Policy and National Book Development Councils in South Asia, New Delhi 23 \& 24 August 1993. 1993. New Delhi: Afro-Asian Book Council.

Hart, G. 1999a. Information literacy education in disadvantaged schools: a case study of project work at a primary school in South Africa. School libraries worldwide, 5(1): 78-96.

Hart, G. 1999b. Ready for the information society? A study of Cape Town's children's librarians. New review of children's literature and librarianship, 5: 169-188.

Hart, G. 2000a. "My kids hate to read up \& those things". Teachers, projects and reading: reflections on a field study of project work. WCED Literacy Indaba [Conference], Cape Town College of Education, Mowbray, 12-13 July 2000. Unpublished paper.

Hart, G. 2000b. Project work as a vehicle for information literacy education in a circuit of South African schools. IFLANET. Available online: www.ifla.org.

Hunt, P. 1994. An introduction to children's literature. Oxford: Oxford University Press.

Jenkins, E. 1993. Children of the sun: selected writers and themes in South African children's literature. Johannesburg: Ravan Press.

Johns, L. 2002. Schools phasing out teaching in Afrikaans. Cape Argus, February 22: 8.

Krashen, S. 1993. The power of reading: insight from the research. Englewood: Libraries Unlimited.

Kruger, J A. 1991. Kinderkeur: 'n gids tot bekroonde Suid-Afrikaanse kleuter-, kinder-en jeugboeke tot 1989. Pretoria: UNISA Press.

Lenake, J. 1996. Children's books in African languages: an overview. In Machet, M. Olën, S, Van der Walt, T. Eds. Other worlds other lives: children's literature experiences. Volume 3. Pretoria: UNISA Press: 107-115.

Machet, M.P. 1993. Publishing and book selling in South Africa with specific reference to the black market. South African journal of library and information science, 61(4): 166-176.

Machet, M. \& Olën, S. 1997. Literacy environment of pupils in urban primary schools. South African journal of library \& information science, 65(2): 77-84.

Machet, M. OlNn, S, Van der Walt, T. 1996. Other worlds other lives: children's literature experiences. Pretoria: UNISA Press.

Machet, M. Olën, S, \& Chamberlain, A. 2001. Young people's reading in South Africa: a pilot project. Pretoria: Children's Literature Research Unit, University of South Africa.

Maddy, Y.L. \& MacCann, D. 1996. African images in juvenile literature: commentaries on neocolonialist fiction. Jefferson: McFarland.

Ogunrombi, S.A. \& Adio, G. 1995. Factors affecting the reading habits of secondary school students. Library review, 44(4): 5057.

Paul, L. 1989. Teaching children's literature in Canada. Signal, 58: 39-74.

READ Educational Trust. 1998. No South African child should fail matric: a submission to all involved in the education of South Africa's children. Braamfontein: READ.

Reading the future: a place for literature in public libraries. 1992. London: Arts Council of Great Britain \& Library Association.

Saltman, J. 1987. Modern Canadian children's books. Toronto: Oxford University Press.

Serote, W M. 2000. Hyenas. Florida Hills: Vivlia.

Streatfield, D. \& Davies, R. 1995. The Library Power Survey report on libraries and young people. London: Library Assocation.

Students shun South African languages. 2001. Sunday Times, 4 March 2001.

Taylor, N. \& Vinjevold, P. 1999. Getting learning right. Johannesburg: Joint Education Trust.

Tötemeyer, AJ. 1984. The racial element in Afrikaans children's and youth literature. D Phil thesis University of Stellenbosch.

Tötemeyer, AJ. 1993. Afro-Afrikaans children's books in a new South Africa? In Cilliers, I. Ed. Towards more understanding: the making and sharing of children's literature in Southern Africa. Cape Town: Juta: 97-107.

Wray,D, Bloom, W \& Hall, N. 1989. Literacy in action. London: Falmer Press. 